\title{
Persepsi terhadap Kemampuan Komunikasi Interpersonal Orang Tua dengan Kecenderungan Kenakalan Remaja
}

\author{
Fadiah Awanis ${ }^{1} \mathcal{E}$ MG. Adiyanti ${ }^{2}$ \\ Fakultas Psikologi Universitas Gadjah Mada
}

\begin{abstract}
This study aimed to determine the relationship between perception of parent's interpersonal communication ability and juvenile delinquency tendency. The hypothesis of this study was the perception of parent's interpersonal communication ability had a negative correlation with juvenile delinquency tendency. Participants consisted of 100 male and female middle adolescents who studied in several senior high school in Yogyakarta. The Perception of Parent's Interpersonal Communication Ability Scale (18 items) and The Tendency of Juvenile Delinquency Scale (25 items) were used in this study. Data were analyzed using Product Moment Pearson Correlation method with SPSS version 21. The result showed that the perception of parent's interpersonal communication ability significantly had negative correlation with juvenile delinquency tendency $(r=-0.295, p<0.01)$. Findings support the opposite relationship between how adolescents perceive the ability of parents' interpersonal relationships with their juvenile delinquency tendency.
\end{abstract}

Keywords: juvenile delinquency; parent's interpersonal communication; perception

Abstrak. Penelitian ini bertujuan untuk mengetahui hubungan antara persepsi terhadap kemampuan komunikasi interpersonal orang tua dengan kecenderungan kenakalan remaja. Hipotesis yang diajukan dalam penelitian ini adalah persepsi terhadap kemampuan komunikasi interpersonal orang tua berkorelasi negatif dengan kecenderungan kenakalan remaja. Partisipan dalam penelitian ini $(N=100)$ merupakan individu usia remaja tengah yang berjenis kelamin laki-laki dan perempuan, dan menempuh pendidikan di beberapa sekolah negeri di Yogyakarta. Skala yang digunakan dalam penelitian ini terdiri dari dua skala yaitu Skala Persepsi terhadap Kemampuan Komunikasi Interpersonal Orang tua, dan Skala Kecenderungan Kenakalan Remaja. Metode analisis data menggunakan teknik analisis korelasi Product Moment Pearson. Hasil penelitian ini diperoleh $r=0,295(p=0,001)$. Hasil tersebut mendukung hubungan negatif antara persepsi remaja terhadap kemampuan hubungan interpersonal orang tua dengan kecenderungan kenakalan remaja.

Kata kunci: kenakalan remaja; komunikasi interpersonal orang tua; persepsi

Setiap orang tua memiliki cara yang berbeda untuk mengomunikasikan nilainilai kehidupan pada remaja. Namun, menurut Sarwono (2013), orang tua harus tetap memperhatikan persepsi remaja, bukan hanya pandangan orang tua sendiri.
Sebab, ketika seorang remaja memandang suatu hal sebagai sebuah ketidakadilan, maka remaja akan menun-jukkan perilaku sesuai dengan panda-ngannya itu sendiri. Remaja biasanya memiliki sudut pandangnya sendiri dalam memandang

\footnotetext{
${ }^{1}$ Korespondensi mengenai isi artikel ini dapat dilakukan melalui fadiah.awanis@mail.ugm.ac.id

2 atau melalui adiyanti_psy@ugm.ac.id 
suatu hal. Memahami remaja memang bukan suatu perkara yang mudah (Sarwono, 2013).

Sementara itu, permasalahan yang sering terjadi di kalangan remaja adalah perilaku kenakalan. Kenakalan remaja dalam bahasa Inggris disebut dengan juvenile delinquency. Kenakalan remaja merupakan perilaku melanggar aturan yang dilakukan oleh anak dibawah umur (biasanya diidentifikasi sebagai individu usia dibawah 18 tahun), yang akan dianggap kriminal apabila dilakukan oleh orang dewasa (APA Dictionary of Psychology, 2007). Di akhir tahun 2016, Polda Metro Jaya merilis indeks kejahatan, dan menemukan bahwa kenakalan remaja di Indonesia mengalami peningkatan sepanjang tahun 2016 (Nailufar, 2016), salah satunya di Kota Yogyakarta.

Kota Yogyakarta, ibukota Daerah Istimewa Yogyakarta sudah dikenal masyarakat luas sebagai Kota Pelajar. Hal tersebut dikarenakan terdapat banyak sekolah dan universitas yang sudah terjamin mutunya dan terakreditasi secara baik di dunia pendidikan, serta banyak sumber daya manusia yang berkualitas di Yogyakarta (Latief, 2015). Namun, terlepas dari predikat yang dimiliki kota Yogyakarta sebagai Kota Pelajar, terdapat beberapa permasalahan yang sebenarnya dapat merusak citra Yogyakarta (Widyatama, 2016).

Pelajar di daerah berhati nyaman ini tidak luput dari perilaku-perilaku negatif (Handika, 2012), seperti vandalisme, perkelahian atau tawuran pelajar, minumminuman beralkohol, melakukan hubungan seks diluar nikah, hingga mengonsumsi narkoba. Ketua Komisi A DPRD DIY, Eko Suwanto dalam wawancaranya bersama Tribun Jogja menyebutkan bahwa kenakalan remaja menjadi salah satu potensi ancaman yang mengganggu keamanan dan ketertiban Daerah Istimewa Yogyakarta (DIY)
(Hidayah, 2016). Dilansir dari suaramerdeka.com (2016), Kapolresta Yogyakarta, Kombes Pol Tommy Wibisono mengatakan bahwa kenakalan remaja masih sering terjadi di Kota Pelajar. Menurut Kepala SATBINMAS Resor Kota Yogyakarta, Kompol Isrowiyah, kenakalan remaja tahun 2016 mengalami peningkatan dari tahun sebelumnya.

Menurut Rice dan Dolgin (2008), salah satu faktor yang dapat menyebabkan kenakalan remaja adalah faktor interpersonal, salah satunya keluarga. Pembentukan perilaku seseorang bermula dari keluarga (Agustiani, 2006). Menurut Teori Ekologi Bronfenbrenner (Santrock, 2012), keluarga merupakan salah satu sistem lingkungan pertama bagi individu, atau biasa dikenal dengan mikrosistem. Dalam mikrosistem, individu menghabiskan banyak waktu dan berinteraksi secara langsung salah satunya dengan orang tua. Komunikasi merupakan aspek yang signifikan terkait kelekatan antara orangtua dengan remaja (Moitra \& Mukherjee, 2012). Komunikasi antara orang tua dengan remaja merupakan interaksi yang terjadi antara dua atau tiga individu yang memiliki keterikatan. Komunikasi antara dua individu (terkadang lebih) yang saling bergantung disebut dengan komunikasi interpersonal (DeVito, 2013).

Ying, et al. (2015) juga menyatakan bahwa salah satu cara atau kunci untuk membangun dan menguatkan hubungan serta kedekatan antara orang tua dengan remaja adalah komunikasi. Komunikasi dapat efektif apabila penerima pesan menginterpretasikan pesan yang diterimanya seperti yang dimaksudkan pengirimnya (Rakhmat, 2012). Psikolog Adelina Syarief, S.E., M.Psi. (Kusmiyati, 2013) mengatakan bahwa sebenarnya faktor utama untuk mencegah timbulnya kenakalan remaja adalah komunikasi orang tua dan anak. Namun, tidak jarang para orang tua justru membuat remaja 
semakin nakal, padahal sebenarnya orang tua bermaksud untuk memahami perubahan yang terjadi pada anaknya (Unayah \& Sabarisman, 2015). Dalam penelitiannya Moitra \& Mukherjee (2012) menjelaskan bahwa keluarga memiliki peran penting dalam perkembangan perilaku kenakalan remaja.

Persepsi adalah pengalaman tentang objek, peristiwa, atau hubunganhubungan yang diperoleh dengan cara menyimpulkan informasi dan menafsirkan pesan (Rakhmat, 2012). Persepsi remaja terhadap kemampuan komunikasi interpersonal orang tua merupakan penilaian remaja terhadap kemampuan orang tua dalam menyampaikan isi pesan. Moitra \& Mukherjee (2012) menemukan bahwa persepsi remaja terhadap komunikasi orang tua yang buruk sangat terkait dengan perilaku kenakalan. Berdasarkan penelitian yang dilakukan oleh Moitra \& Mukherjee (2012) pada remaja di India ditemukan bahwa persepsi remaja terhadap komunikasi orang tua yang buruk menunjukkaan tingginya perilaku kenakalan. Sebaliknya, persepsi remaja terhadap komunikasi orang tua yang baik menunjukkan tingkat perilaku kenakalan yang rendah.

Oleh sebab itu, Sarwono (2013) menyatakan bahwa dibutuhkan kemampuan tertentu untuk memahami pandangan remaja, begitu pula dengan perasaan yang ada dibalik pandangan tersebut. Oleh karena itu, dalam penelitian ini, peneliti mencari tahu mengenai kecenderungan remaja melakukan kenakalan dilihat dari persepsi remaja terhadap kemampuan komunikasi interpersonal orang tua. Hipotesis yang diajukan dalam penelitian ini adalah persepsi terhadap kemampuan komunikasi interpersonal orang tua berkorelasi negatif dengan kecenderungan kenakalan remaja.

\section{Metode}

Partisipan dalam penelitian ini berjumlah seratus (100) remaja tengah yang menempuh pendidikan formal di beberapa Sekolah Menengah Atas di Yogyakarta. Terdapat dua skala yang digunakan dalam penelitian ini, yaitu Skala Kecenderungan Kenakalan Remaja (Murni, 2004) dan Skala Kemampuan Komunikasi Interpersonal (Anggraini, 2003). Dilakukan modifikasi pada skala kedua menjadi Skala Persepsi terhadap Kemampuan Komunikasi Interpersonal Orang tua. Dalam penelitian ini analisis dilakukan dengan menggunakan teknik korelasi Product Moment Pearson untuk mengetahui hubungan antara variabel tergantung dan variabel bebas penelitian.

\section{Hasil}

Hasil analisis menunjukkan koefisien korelasi sebesar $r=-0,295 \quad(p<0,01)$. Hal tersebut menunjukkan bahwa persepsi terhadap kemampuan komunikasi interpersonal orang tua memiliki hubungan negatif yang signifikan dengan kecenderungan kenakalan remaja demikian pula sebaliknya.

Dalam penelitian ini juga dilakukan analisis untuk melihat perbedaan kecenderungan kenakalan remaja berdasarkan jenis kelamin menggunakan Independent Sample t-test dengan $T=2,695 \quad(p=0,008$, $p<0,05)$, hal tersebut menunjukkan bahwa terdapat perbedaan kecenderungan kenakalan remaja antara remaja laki-laki dan perempuan. Selain itu, data persepsi terhadap kemampuan komunikasi interpersonal orang tua didapatkan $T=-0,212$ $(p=0,832, \quad p>0,05)$ yang menunjukkan bahwa tidak terdapat perbedaan persepsi tehadap kemampuan komunikasi interper- 
sonal orang tua antara remaja laki-laki dan perempuan.

Berdasarkan hasil uji beda menggunakan One-Way ANOVA untuk variabel kecenderungan kenakalan remaja berdasarkan usia ditemukan bahwa $F=2,174$ $(p=0,119, p>0,05)$, hal tersebut menunjukkan bahwa tidak terdapat perbedaan kecenderungan kenakalan antara remaja usia 15, 16, dan 17. Hasil uji beda persepsi terhadap kemampuan komunikasi interpersonal orang tua ditemukan $F=0,113$ $(p=0,893, p>0,05)$ yang berarti bahwa tidak terdapat perbedaan persepsi antara remaja usia 15, 16, dan 17.

\section{Diskusi}

Kecenderungan kenakalan remaja dapat disebabkan oleh banyak faktor, salah satunya keluarga. Keluarga merupakan tempat pertama bagi individu dalam mempelajari kehidupan. Komunikasi dalam keluarga menjadi salah satu hal yang penting sebagai sarana individu untuk belajar. Kemampuan individu dalam menyesuaikan komunikasi berdasarkan konteks dan dengan siapa individu berkomunikasi disebut sebagai kemampuan interpersonal. Individu yang memiliki kemampuan komunikasi yang baik akan menghasilkan umpan balik dari lawan bicaranya yang sesuai dengan tujuan pesan. Hal tersebut merupakan tujuan dari terjalinnya komunikasi interpersonal (Putri, 2015).

Hipotesis dalam penelitian ini adalah persepsi terhadap kemampuan komunikasi interpersonal orang tua berkorelasi negatif dengan kecenderungan kenakalan remaja. Berdasarkan hasil analisis korelasi yang telah dilakukan, didapatkan koefisien korelasi $r=-0,295 \quad(p<0,01)$. Hal tersebut menunjukkan bahwa persepsi terhadap kemampuan komunikasi interpersonal orang tua memiliki hubungan negatif dengan kecenderungan kenakalan remaja. Hal ini sejalan dengan penelitian yang dilakukan oleh Moitra dan Mukherjee (2012) bahwa persepsi remaja terhadap komunikasi orang tua yang buruk terkait dengan perilaku kenakalan yang tinggi. Begitu pun sebaliknya, persepsi remaja terhadap komunikasi orang tua yang baik terkait dengan perilaku kenakalan yang rendah. Selain itu, skor mean empirik $(38,6)$ variabel kecenderungan kenakalan remaja dalam penelitian ini lebih rendah daripada skor mean hipotetiknya (75). Hal tersebut dapat dikarenakan bahwa partisipan dalam penelitian ini bukan merupakan individu yang sudah melakukan kenakalan, tetapi individu yang belum pasti melakukan kenakalan. Oleh karena itu, skor mean empirik dalam penelitian ini cenderung rendah.

Komunikasi remaja dan orang tua yang kurang baik dapat menjadi salah satu penyebab kenakalan. Menurut Clark dan Shields (1997), komunikasi dapat menjadi salah satu faktor yang menyebabkan individu melakukan kenakalan. Komunikasi remaja dan orang tua akan efektif apabila penerima menginterpretasi pesan seperti yang dimaksudkan pengirim. Persepsi menjadi salah satu hal penting dalam komunikasi. Ketika seseorang memersepsi pesan berbeda dengan yang dimaksud pengirimnya, maka makna pesan tersebut akan berbeda. Persepsi merupakan penilaian dan interpretasi individu terhadap suatu objek, individu lain, perilaku, atau kondisi tertentu menggunakan panca indera (Wahyuni, 2010). Dalam hal ini, remaja memersepsi komunikasi orang tua berdasarkan kemampuan orang tua dalam menyampaikan pesan.

Karakteristik partisipan dalam penelitian ini adalah individu usia 15, 16, dan 17 tahun, serta berjenis kelamin lakilaki dan perempuan. Sebanyak 52\% partisipan dalam penelitian ini berusia 16 
tahun. Berdasarkan hasil uji ANOVA ditemukan $p=0,119$, hal tersebut menunjukkan bahwa tidak terdapat perbedaan kecenderungan kenakalan antara remaja usia 15, 16, maupun 17 tahun. Hasil penelitian Modecki (2008) menunjukkan bahwa kemungkinan individu usia remaja dalam melakukan kenakalan cenderung tinggi.

Sementara itu, sebanyak 60 partisipan dalam penelitian ini adalah perempuan, sedangkan 40 partisipan lainnya adalah laki-laki. Hasil uji analisis tambahan dengan menggunakan metode $t$-test dalam penelitian ini sejalan dengan pernyataan Synder (dalam Cobb, 2007) bahwa perempuan lebih cenderung tidak terlibat dalam kenakalan, hal tersebut dibuktikan dari hasil yang menunjukkan $p=0,008$ $(p<0,05)$. Hasil tersebut mengindikasikan bahwa terdapat perbedaan kecenderungan kenakalan antara laki-laki dan perempuan. Perbedaan tersebut dapat dilihat dari ratarata (mean) pada masing-masing data jenis kelamin. Partisipan laki-laki memiliki mean $=41,25$, sedangkan partisipan perempuan memiliki mean=36,75. Rata-rata untuk data kecenderungan kenakalan partisipan laki-laki lebih tinggi dari partisipan perempuan meskipun jumlah partisipan laki-laki dalam penelitian ini lebih sedikit. Hasil penelitian Modecki (2008) juga menunjukkan bahwa laki-laki cenderung lebih terlibat dalam kenakalan dibandingkan perempuan.

Dalam penelitian ini juga didapatkan informasi terkait orang tua yang bekerja dan tempat tinggal. Dari hasil uji t-test yang telah dilakukan, dapat diketahui bahwa tidak terdapat perbedaan kecenderungan kenakalan antara remaja yang tinggal dengan orang tua dan yang tidak tinggal dengan orang tua. Begitu pula dengan persepsi kemampuan komunikasi interpersonal orang tua, tidak terdapat perbedaan antara partisipan yang tinggal dengan orang tua dan yang tidak.
Sementara itu, berdasarkan data yang sudah didapatkan, ditemukan bahwa ayah dan ibu partisipan yang bekerja berturutturut sebanyak $94 \%$ dan $57 \%$. Berdasarkan hasil analisis tambahan yang dilakukan, tidak terdapat perbedaan kecenderungan kenakalan antara partisipan dengan ayah yang bekerja ataupun tidak, maupun antara partisipan dengan ibu yang bekerja ataupun tidak. Begitu pula dengan variabel persepsi kemampuan komunikasi interpersonal orang tua, tidak terdapat perbedaan persepsi terhadap kemampuan komunikasi interpersonal orang tua antara partisipan dengan ayah yang bekerja dan tidak, serta ibu yang bekerja dan tidak.

Hal tersebut dapat dikarenakan orang tua tidak memiliki pengaruh yang cukup besar pada individu di usia remaja. Pada usia tersebut, individu lebih banyak menghabiskan waktu bersama teman sebaya. Menurut Cobb (2007), teman memiliki pengaruh yang penting dalam kehidupan seorang remaja. Criktenmihalyi dan Larson (dalam Agustiani, 2006) juga mengungkapkan hal yang sama bahwa teman merupakan bagian penting dalam keseharian remaja dan merupakan tempat untuk menghabiskan waktu, tempat berbicara, dan tempat berbagi kesenangan dan kebebasan. Teman sebaya dapat memberikan pengaruh positif maupun negatif dalam hidup seorang individu usia remaja. Oleh karena itu, peran orang tua sangat penting sebagai kontrol perilaku remaja dari lingkungan sekitar.

\section{Kesimpulan}

Berdasarkan penelitian yang telah dilakukan kepada partisipan usia remaja tengah, ditemukan hasil bahwa persepsi kemampuan komunikasi interpersonal orang tua memiliki hubungan negatif yang signifikan dengan kecenderungan kenakalan remaja. Dalam hal ini berarti, semakin 
baik persepsi terhadap kemampuan komunikasi interpersonal orang tua, maka semakin rendah kecenderungan kenakalan remaja. Begitu pun sebaliknya, semakin buruk persepsi terhadap kemampuan komunikasi interpersonal orang tua, maka semakin tinggi kecenderungan kenakalan remaja. Hasil penelitian juga menunjukkan bahwa individu usia remaja memiliki kemungkinan yang tinggi dalam melakukan kenakalan. Selain itu, perempuan cenderung tidak terlibat dalam perilaku kenakalan dibandingkan laki-laki. Dalam penelitian ini juga ditemukan bahwa orang tua tidak memiliki pengaruh yang cukup besar pada individu usia remaja karena pada usia tersebut individu lebih banyak menghabiskan waktu dengan teman sebaya. Hal ini ditunjukkan dengan hasil analisis tambahan yang menunjuk-kan bahwa tidak terdapat perbedaan kecenderungan kenakalan antara partisipan dengan orangua yang bekerja atau tidak bekerja.

\section{Saran}

Hasil dari penelitian ini diharapkan dapat menjadi tambahan informasi dalam pembuatan intervensi atau pelatihan komunikasi antara orang tua dan remaja atau dapat dilakukan terapi keluarga. Dalam pembuatan intervensi tersebut terdapat beberapa hal yang harus diperhatikan, seperti membangun percaya diri dan harga diri individu, serta membangun karakter individu dan menanamkan nilai positif.

Peneliti selanjutnya dapat melakukan penelitian mengenai literasi perkembangan remaja pada orang tua. Penelitian tersebut dapat menjadi sarana orang tua untuk mengetahui perkembangan remaja dan menjadi acuan orang tua dalam menerapkan pola asuh, seperti cara berkomunikasi yang sesuai dengan remaja. Hal tersebut dikarenakan individu di usia remaja lebih banyak menghabiskan waktu di luar rumah dengan teman sebaya. Selain itu, peneliti selanjutnya juga dapat melakukan penelitian perbedaan bentuk kenakalan yang dilakukan antara remaja laki-laki dan perempuan, maupun perbedaan bentuk kenakalan pada individu usia remaja tengah.

\section{Daftar Pustaka}

Agustiani, H. (2006). Psikologi perkembangan: Pendekatan ekologi kaitannya dengan konsep diri dan penyesuaian diri remaja. Bandung: PT. Refika Aditama.

American Psychological Association. (2007). APA dictionary of psychology. Washington DC: American Psychological Association.

Anggraini, N. (2003). Peran keterampilan menyimak dan keterampilan berbicara dengan kemampuan komunikasi interpersonal pada siswa SMU. Naskah tidak dipublikasikan. Fakultas Psikologi Universitas Gadjah Mada, Yogyakarta.

Clark, R. D., \& Shields, G. (1997). Family communication and delinquency. Adolescence, 32, 81.

Cobb, N. J. (2007). Adolescence: Continuity, change, and diversity (6 ed.). New York: The McGraw-Hill Companies, Inc.

DeVito, J. A. (2013). The interpersonal communication book (13 ed.). New Jersey: Pearson Education, Inc.

Handika, W. (2012, Nopember). Mengapa Yogyakarta disebut kota pelajar? Diunduh dari: wibihandika.wordpress.com: https://wibihandika.wordpress.com 2012/11/15/mengapa-yogyakartadisebut-kota-pelajar/ tanggal 16 Juli 2017.

Hidayah, K. (2016, December). Kenakalan remaja masuk daftar potensi ancaman di DIY. Diunduh dari: 
http://jogja.tribunnews.com/2016/12

L14/kenakalan-remaja-masuk-

daftar-potensi-ancaman-di-diy

tanggal 12 Juni 2017.

Kusmiyati (2013, September). Berbagai perilaku kenakalan remaja yang mengkhawatirkan. Diunduh dari https://www.liputan6.com/health/re ad/688614/berbagai-perilaku-

kenakalan-remaja-yangmengkhawatirkan tanggal 12 Juni 2017.

Latief. (2015, Juni). Jogja kota pelajar dan budaya. Diunduh dari: http://www.kompasiana.com/latief mnc/jogja-kota-pelajar-danbudaya 55094eba813311eb01b1e174 tanggal 16 Juli 2017.

Modecki, L. K. (2008). Addressing gaps in the maturity of judgement literature: Age differences and delinquency. Law and Human Behavior, 32, 78-91. doi: 10.1007/ s10979-007-9087-7.

Moitra, T., \& Mukherjee, I. (2012). Parentadolescent communication and deliquency: a comparative studi in kolkata, india. Europe's Journal of Psychology, 8, 74-94. doi: 10.5964/ ejop.v8i1.299

Murni, A. (2004). Hubungan persepsi terhadap keharmonisan keluarga dan pemantauan diri dengan kecenderungan perilaku delinkuen pada remaja. Naskah tidak dipublikasikan. Fakultas Psikologi Universitas Gadjah Mada, Yogyakarta.

Nailufar, N. N. (2016, Desember 29). Ini 11 jenis kejahatan yang menonjol selama 2016. Diunduh Juni 12, 2017, dari Kompas.com:

http://megapolitan.kompas.com/rea d/2016/12/29/17470511/ini.11.jenis.k ejahatan.yang.menonjol.selama.201 6
Putri, N. T. (2015). Hubungan komunikasi interpersonal orang tua dengan perilaku seksual pranikah remaja di kota padang. (Tesis tidak dipublikasikan). Fakultas Psikologi Universitas Gadjah Mada, Yogyakarta.

Rakhmat, J. (2012). Psikologi komunikasi. Bandung: PT. Remaja Rosdakarya.

Rice, F. P., \& Dolgin, K. G. (2008). The adolescent development, relationships, and culture (12 ed.). Boston: Pearson Education, Inc.

Santrock, J. W. (2012). Perkembangan masa hidup (13 ed.). (N. I. Sallama, Ed., \& B. Widyasinta, Trans.) Jakarta: Erlangga.

Sarwono, S. W. (2013). Psikologi remaja. Jakarta: PT. RajaGrafindo Persada.

Suaramerdeka.com. (2016, September). Kapolresta jogja tak ingin beri toleransi aksi kenakalan remaja. Diunduh dari: http://berita.suaramerdeka.com/kap olresta-jogja-tak-ingin-beri-

toleransi-aksi-kenakalan-remaja/ Oktober 2016

Unayah, N., \& Sabarisman, M. (2015). Fenomena kenakalan remaja dan kriminalitas. Jakarta: Puslitbang Kesejahteraan Sosial, Kementerian Sosial RI.

Wahyuni, S. (2010). Hubungan antara persepsi terhadap pola asuh otoriter orang tua dan kemampuan berempati dengan kecenderungan berperilaku bullying pada remaja. Naskah Tidak Dipublikasikan. Fakultas Psikologi Universitas Gadjah Mada, Yogyakarta.

Widyatama, B. (2016, Februari). Yogyakarta sebagai kota pendidikan: Antara jargon dan realita. Diunduh dari: http://www.kompasiana.com/bastia nwidyatama/yogyakarta-sebagaikota-pendidikan-antara-jargon-danrealita 56d17c1ad17a61e23c15e0f0 tanggal 16 Juli 2017. 
Ying, L., Ma, F., Huang, H., Guo, X., Chen, C., \& Xu, F. (2015). Parental monitoring, parent-adolescent communication, and adolescent's trust in their parents in china. (V. Eapen, Ed.) PLOS One. doi: $\underline{10.1371 / \text { journal.pone. } 013473}$ 